\title{
Ideology, Identity and Power: The Gikuyu Female Referencing System
}

\author{
Evelyn Mahero
}

\author{
Laikipia University, Kenya \\ evemahero@gmail.com
}

\begin{abstract}
Language is a means through which ideology and power is passed on from one generation to another in the society. Referencing is a way of life in all communities, things and people are named in a certain manner. People are given references that communicate certain messages to those who hold the reference and the community at large. Analysing the Gikuyu female references reveals that the references are discriminative of women and to some extent deny them power by skillfully communicating an oppressive message to the female person among the Agikuyu. This study aims at identifying and analyzing these references to show how they portray skewed power relations. This study is guided by Critical Discourse Analysis theory CDA, specifically Discourse Historical approach (DHA). The data consisted of the Agikuyu female references which were collected purposefully. The results show that many Gikuyu references on women are discriminative, and portray power and dominance over women. The references also reveal the traditional ideologies that stereotype women, reflecting the culture and belief system of the community. It also gives insights in to the fight for gender equity in this community. Those interested in power relations, identity, ideology and culture will find this paper useful.

Keywords- Ideology, Identity, Power, Female Referencing System.
\end{abstract}

\section{INTRODUCTION}

Studying ideology, according to Thompson (1990), requires an investigation of the ways in which meaning is constructed and conveyed by symbolic forms which are also the systems of belief of various kinds in daily life. This applies well to this study since it is interested in the symbolic forms that are used to refer to women in the Gikuyu Language as micro features and how they bring out macro structures of ideology.

Van Djik reports that a cognitive component should be included in the theory of ideology. He calls this the shared mental representations of language users (1998:5). Van Djik (1997) gives three aspects of the social cognition. The first one is through knowledge from a cultural perspective, which refers to the knowledge shared by all competent members of a society.This kind of knowledge is seen as a common ground. The second aspect of social cognition is the attitudes, which refers to socially shared opinions of a group of people while the third aspect is ideology. These three ways in which van Djik looks at social cognition are important to this study because the study looks at how the symbols of reference affect women in terms of ideology power and identity. They are viewed as common knowledge and accepted as community references for female persons among the Gikuyu but indirectly they are sources of discrimination. According to van Djik ideologies are used by dominant groups to reproduce and legitimize their domination over others. The socio-cognitive aspects bridge the gap between the micro level of discourse and the macro level that affect people in society through the social practices. (van Djik, 2001:115).

According to Thompson (1990), the interpretation of ideology necessarily involves socio-historical analysis of structural relationships of power in which the role of symbolic form is considered. A critical reflection of power and domination, can be done through the analysis and interpretation of ideology.Foucault (1980:61) argues that power and knowledge are related and every human relationship is a power struggle. The ever present power in the society has the abilityto produce and constrain truth and that discourse is related to power because it operates on rules of exclusion. In this study, it was observed that men have no equivalent reference to the abusive oppressive and discriminative references of women. Since men are more powerful than women they are deliberately excluded when it comes to negative references.

CDA views discourse as an instrument of power and control. This means that discourse is what is used to control social reality, and though language has no direct power, when it is used by the powerful in the society it gains power, and this way language may bring inequalities, (Fairclough, 2000: 49).According to Cameron (2001:24) the main claim of CDA which is also the view adopted in this study is the fact that the way certain realities get talked 
about or written about especially the choices speakers and writers make are not just random but ideologically patterned. These choices do much especially in relation to naturalization of particular social arrangements which serve certain specific interests so that with time they may come to seem like the only possible or natural arrangements.

Gender is one of the main variable in this study and according to Mama 1996), gender is a stereotyped concept. Societal aspects of gender are (passed on from generation to generation through several channels, such oral and written tradition. The current study is concerned with the references of the female person which seem to discriminate and deny women power in their community. These references bring about unequal power relations. Language is connected to power and societal ideologies and so gender relations are propagated through language.

Cameron talks about identity as constantly changing rather thana fixed concept. Language use is one of the social practices through which people as sert identities. It is also among the social practices through which people enact relations of domination and subordination. Language is a source of understanding how identity and dominance are constructed in verbal interaction (Cameron 2001:170). The current study is interested in how language is used to give identity to Gikuyu women and how this affects power relations.

\section{The Gikuyu of Kenya}

Kenya is a multilingual country (Muaka, 2011) and also to a high degree portrays aspects of ethno-linguistic fragmentation (Posner, 2004). There is an aspect of language families and sub-families (Githiora, 2002). The largest language family is the Bantu, followed by Nilotes and Cushites then the rest (Webb \& Kembo - Sure, 2000).The Gikuyu speakers belong to the Kamba - Gikuyu subgroup of Bantu spoken in Nairobi and the southern and southwestern slopes of Mt. Kenya in Kenya (Guthrie, 1967).Although it is not clear whether the Gikuyu language has dialects, Macharia (2011:7) reports that the Gikuyu Language has five dialects, Southern Gikuyu spoken in Kiambu and Murang'a, Mathira spoken in Nyeri, Gichugu spoken in northern Kirinyaga, and Ndia, spoken in Southern Kirinyaga. According to the National Bureau of statistics (2009), Gikuyu language is spoken by about 6.8 million which is about $17 \%$ of the Kenyan population. The Agikuyu therefore constitute the largest ethnic community in Kenya.

\section{Women and discrimination}

The female person has faced severe discrimination for a long time in Africa and beyond. Some of the apparatus of this discrimination and power imbalance are ordinary day to day processes and activities. No one may see these processes and activities as taking part in the discrimination of the female persons in Gikuyu community. It is only through unravelling of the discourses of these processes that the discrimination and power inequality get exposed. Some of these apparatus include the referencing system of womenin the Gikuyu community. This study set out to establish how the Gikuyu community references relate to the discrimination of the female person in terms of Identity and power. The reference system is part of the ideology andtradition of the Gikuyu people. Specifically, this study sougt to identify the references used to refer to the female person among the Gikuyu speakers; explain the meaning of thosereferences and how they discriminate the female person in terms of power and identity among the Gikuyu speakers; and to analyse the discursive strategies within the references of the Gikuyu female persons among the Gikuyu speakers.

\section{Critical Discourse Analysis (CDA)}

Critical Discourse Analysis (CDA) which was initially Critical Linguistics (CL) is the theoretical framework underpinning the current study. According to Fairclough and Wodak (2001: 148), CDA is the only theory of language that regards language as a social practice. CDA analyses structural relationships of dominance power and control as manifested in language. The current study is interested in power and discrimination of women through references used among the Gikuyu.

CDA is a multidisciplinary approach of looking at language. It draws from critical theory, semiotics and social psychology. The conceptual and analytical apparatus of CDA are taken from Structural Linguistics and Critical Theory. According to CDA social reality is constructed in and through discourse and language is seen as a means of communication (van Djik 1998; Wodak 2001). According to Fairclough (2000: 164) the basic assumptions of CDA are; all discourses are historical and can therefore be understood with reference to their context; language is a social phenomenon, there is a social relationship between language and society; texts are relevant units of language in communication; and readers and hearers are not passive recipients. This alludes to the fact that micro linguistic structures influence macro social and economic structures of the society; they influence people to behave in a certain way. This is the main is sue in the current study. To find out how these Gikuyu references portray women in terms of social structures and social expectations.

CDA emphasizes the fact that discourse is ideological and ideology is a systematic body of ideas organized from a particular point of view (Hodge \& Kress, 
1993:6). According to Fairclough (1998), CDA advocates for increased awareness in the use of language to improve the welfare of marginalized groups. Gikuyu female persons whose references are being studied in this research are part of the general marginalized group of women in Kenya, Africa and the world over. The historical injustices of women are immense. CDA reveals the hidden agenda of discourse according to Cameron (2001).

\section{Discourse Historical Approach}

This sub-theory of CDA advocated mainly by Wodak (2001) emphasizes the fact that language is not merely for passing and sharing information but also for maintaining and propagating ideology and power. DHA is concerned with exposing unequal relations embedded in language and making better the condition of those that are disadvantaged in the society.

The qualitative and systematic analysis of DHA examines four main contextual levels. They include the relationship between and among texts, utterances, genres and discourses; non -linguistic sociological effect, his torical context of texts and the institutional reference frame.KhosraviNik (2010) reports that within the focus of representation of social groups in the text the linguistic (micro) mechanisms may affect the perspectivization of the representation of certain social groups through three distinct yet interwoven levels: social actors, social actions and argumentation. These levels correspond to referential, predication and argumentation strategies proposed by discourse Historical Approach DHA(Unger, Wodak \& Khosravinik, 2016).

The current study concentrates on the kind of references given to Gikuyu women and the meaning of these references and how they portray women in terms of power and identity. This paper will mainly dwell on the first level of analysis then briefly merge this level with the rest of the levels. Emphasis is put on the linguistic mechanisms which have an impact on the qualities of the referential strategies used to refer to actors as in-groups and outgroups. According to KhosraviNik (2010: 64) naming of actors may be by, functionalization (what they do or what functions they carry out), aggression (if the actors are referred to as collective entity), along with the positioning of Us/Them categorization through the use of pronouns, status, position among others. This is important to consider in the process of perspectivization.

\section{METHOD}

The data for the current study is limited to the female references of the Gikuyu speakers. The data was collected purposefully, translated and analysed qualitatively to show theidentity of women and the power relation portrayed by the references. The data was collected based on the principle of Mugenda (2003) who posits that in purposeful sampling, subjects are handpicked because they are informative and have the required characteristics.

\section{RESULTS AND DISCUSSIONS Mutumia \\ Translation: One who keeps quiet}

This term used to refer to a woman means one who keeps quiet. This speaks of a woman's expected character and behavior. It communicates the fact that according to the expectations of the Gikuyu people a woman should keep quiet at all times. Women have no opportunity to talk or raise issues. They should listen and follow the opinions of men regarding all issues in the society. According to Foucault (1980) power and knowledge are related and therefore every human relationship is a power struggle. This reference provides certain oppressive knowledge to the woman that should control and influence her character. The woman is therefore assumed not to have the requisite knowledge of important issues in life thus her opinion is irrelevant-she should keep quiet.

\section{Mundumuka}

Translation: One who came

This term is used to refer to a married woman in relation to the fact that she left her home and came to live in her husband's home. She is considered as an outsider who has joined the family, a stranger. This brings out the idea of 'us' and 'them', 'in' and 'out' group, a principle of inclusion and exclusion (KhosraviNik 2016). Cameron (2001:15) reports that people's understanding of the world around them is not merely expressed in their discoursebut is rather shaped by the ways of using language which people have availed to them. A woman with this reference is likely to believe that she doesn't belong and she has no power to influence anything.

\section{Mundu wa nja}

Translation: One who does not belong, one from outside her husband's family

This is also used to refer to a wife as someone who does not belong to the husband's family, as an outsider who should be handled with care. This micro linguistic reference is supposed to promote the social macro structure that a woman should know she does not fully belong to her husband's family. She should know she is an outsider and so she has no say. This still brings out the idea of us and them, in and out group (KhosraviNik 2016). By constantly 
reminding her that she does not belong, she is a stranger, an outsider, she is alienated and psychologically denied power to assert herself as a member of the family whose voice over important is sues should be considered.

Nyina wa......or wa......

Translation: Mother of.... (accompanied by the name of the child if she has children or husband

A woman is named by the name of her child especially the first born who is normally named after one of her husband's parents, for instance Nyina Wa Kimani, Nyina Wa Njoki and so on, if she has no child she is referred to by her husband's name, for instance Wa Njoroge, Wa Njau. This highlights those who are related to the woman and not the woman herself. Therefore the identity of the woman is not independent others. She doesn't have an identity of her own apart from that of her husband or her husband's children.A woman's worth or relevance is thus validated by others as sociated with her- husband or children. Those who don't get married or those who don't get children in marriage are find themselves in a more awkward situation since this referencing has been taken as a standard way, the acceptable reference for grown up women.

\section{Mkoma thi}

Translation: One who sleeps down on the floor

When a woman gives birth she is expected to separate herself from her husband and sleep down near the fire place with the baby. This is because after giving birth, the woman is considered unclean and therefore should not share a bed with her husband until after some time. She was also separated to keep her husband away from the disturbances of the new born. The fact that the society has already determined where and what a woman should do already denies her power to make decisions thus she has to follow the oppressive dictates of the community.

\section{Gichokio}

Translation: One who comes out of her marriage

In the Gikuyu community a woman who reaches maturity is expected to get married and stay at her husband's house. When such a woman gets problems and has to return to her parent's house she is regarded a disgrace and a social mis fit and given this seemingly abusive negative reference.

This makes the woman whose marriage has failed shameful, she has no power to make decisions or fully participate in social activities in her parent's house since she does not belong there but belongs to her husband's house where she is also considered a person who just came. The research noted that there was no equivalent reference for a man who cannot put up with his wife. This portrayed some kind of hidden discrimination. According to Cameron (2001:51),
CDA looks for ideological significance of the choices speakers and writers make. This brings out the fact that CDA is concerned with the hidden agenda in discourse, which makes discourse function not only as language but as a social practice that constructs the object of which it purports to speak.

\section{Kiheti}

Translation: A prostitute

Among the Gikuyu a woman is expected to have a single husband and settle in her husband's house. However if she does not get married and has men friends she is given this abusive reference that also leads to loss of esteem and powerlessness.

\section{Further observation made from the data The morphemes $G i-K i$}

This morpheme pair that is used in some of the references is used to refer to things also. This makes women be classified in the same manner as things reducing the woman to an object. It is also notable that the references with this morpheme pair are those that portray women negatively: Gichokiothat woman who could not manage her marriage and had to go back to her parents' home, and secondly Kiheti which implies a woman who is a prostitute. It is also notable that there is no equivalent words for a man who cannot handle or manage a wife and one who has multiple sexual partners.

\section{Conclusion}

The analys is of the research data in this studyhas shown that the Gikuyu speakers have a systematic referencing system for women and these references have specific condescendingmeaning. The expectations of these references are discriminative and oppressive of the Gikuyu women. This is what brings about inequality in the power relations between men and women among the Gikuyu speakers because they portray women as people who are ignorant and weak and therefore should be dominated and controlled by men. These references were deliberately created to fix the woman in a certain position of subordination in society. This is so because according to this study those who dominate discourse dominate power and control macro structures in the society.

\section{REFERENCES}

[1] Thompson, J.B. (1990): Ideology and modern culture. Cambridge: Polity Press.

[2] Van Dijk, A.T. (1997). Discourse as structure and process of discourse studies: A multidisciplinary introduction. Volume I. SAGE Publications, London

[3] Van Dijk, T. (2001). Multidisciplinary CDA. In (Eds.). Wodak, R. and Meyer, M. Methods of Critical 
Discourse Analysis: Introducing Qualitative Methods. London: Sage

[4] Fairclough, N. (2000). 'The discourse of social exclusion“. In: Reisigl, M./Wodak, R. (eds.) The

Semiotics of Racism. Approaches in Critical Discourse Analysis. Vienna: Passagen Verlag, 65-84

[5] Cameron, D. (2001). Working with Spoken Discourse. London: Sage Mama 1996),

[6] Muaka, L. (2011) Language perceptions and identity among Kenyan speakers. In G. E. Bokamba, R. K. Shosted and B. T. Ayalew (eds) Selected Proceedings of the 40th Annual Conference of African Linguistics 217-230. Sommerville, MA: Cascadilla Proceedings Project.

[7] Posner, D. (2004). "Measuring Ethnic Fractionalization in Africa." American Journal of Political Science 48 (4): 849-63

[8] Githiora, C. (2002). Sheng: Peer language, Swahili dialect or emerging creole? Journal of African Cultural Studies, 15(2), 159-181. doi:http://dx.doi.org/10.1080/1369681022000042637

[9] Kembo-Sure and Webb, V. (2002) Languages in Competition. In V.Webb and Kembo-Sure (eds)African Voices: An Introduction to Languages and Linguistics of Africa. (pp 109-132). Cape Town: Oxford University Press.

[10] Guthrie, M. (1967). The classification of the Bantu languages. London: Dawson's of Pall Mall

[11] Macharia, D. (2011). Phonological variation and change in Gikuyu: A case study of Mathira dialect in Kenya. Unpublished MA Thesis, Kenyatta University

[12] 2009 Population and Housing Census Results (2010). Population Distribution - 10 Least Populated Counties. Nairobi. Kenya.

[13] Van Dijk, A.T. (1997). Discourse as structure and process of discourse studies: A multidisciplinary introduction. Volume I. SAGE Publications, London.

[14] Wodak, R. (2001). The Discourse - Historical Approach, pp. 63-94. In (Eds.). Wodak, R. and Meyer, M. Methods of Critical Discourse Analysis: Introducing Qualitative Method. London: Sage

[15] Hodge, B. \& Kress, G. R. (1993). Language as ideology. London: Routledge

[16] Fairclough, N. (1989). Language and Power. New York: Longman

[17] KhosraviNik, M. (2010). Actor descriptions, action attributions, and argumentation: towards a systemization of CDA analytical categories in the representation of social groups. Critical Discourse Studies, 7: 1, 55-72.
[18] Unger, J., Wodak, R. \& Khosravinik, M. (2016). Critical discourse studies and social media data. In D. Silverman (Ed.). Qualitative research (pp. 277-293). London: Sage

[19] Mugenda, O.N \&Mugenda, A.G. (2003).Research Methods: A Quantitave and Qualitative Approach .Nairobi: ACTS press.

[20] Foucault, M., \& Gordon, C. (1980). Power/knowledge: Selected interviews and other writings, 1972-1977. New York: Pantheon Books.

[21] Dijk, T. van 1997a. Cognitive context models and discourse. In M. Stamenow (Ed.). Language Structure,Discourse and the Access to Consciousness.(pp.189-226).

[22] Amsterdam: Benjamins. Available: http://www.dis courses.org 